\title{
EU MILITARY OPERATION SOPHIA - ANALYSING THE SHORTFALLS
}

\author{
Marius PRICOPI \\ pricopi.marius@armyacademy.ro \\ “NICOLAE BĂLCESCU” LAND FORCES ACADEMY, SIBIU, ROMANIA
}

\begin{abstract}
:
Facing the current issue of migration, European Union leaders managed to scrap together a (widely contested) plan for the redistribution of asylum seekers between the member states. But they also undertook pro-active measures to counter illegal migration; such is the case of the military Operation Sophia.

In this paper we do not disavow in any way the existence and necessity of Operation Sophia. Instead, as a way to hereafter identify new opportunities to enhance its' efficiency, we analyse the criticism brought against it, which mainly concerns: the lack of full transparency, the fosterage of illegal migration and the fail to address the root causes of the on-going migration crisis.
\end{abstract}

\section{KEYWORDS:}

European Union, Libya, military operation, Sophia

\section{Introduction}

No one can currently deny the fact that migration has rapidly become a major issue in the European Union (EU). Tackling migration has generated gaps in the European community, has given new impetus to extremist parties and their advocates and even risks ending the career of otherwise successful and much acclaimed political leaders (the case of Angela Merkel).

As part of a broader strategy to respond to the endless flow of migrants the EU launched, over a year ago, a new military operation named „Sophia”. But in spite of the major successes that it scored, Operation Sophia lacks the public notoriety it deserves. In the hope of stimulating an academic debate around it we submit, in the following, an overview of Operation Sophia and an honest analysis of its' main shortfalls - analysis necessary to also increase its' efficiency, building on the already indisputable achievements that Operation Sophia made possible. 


\section{Methodology}

In writing this paper we used, as a research method, the analysis and synthesis of social documents, as it was best described in a comprehensive compendium on scientific methodology in social sciences (Chelcea, 2004).

\section{Overview of Operation Sophia}

The migration crisis had been going on for some time, but the event that triggered the military response of the EU was the sinking, in April 2015, of a boat carrying approximately 700 migrants, near the Italian island of Lampedusa, resulting in the death of almost all its passengers. This was the distress call that made European leadership realize that concrete measures had to be taken.

By the Council Decision 2015/778 of 18 May 2015, EU leaders determined to conduct a military crisis management operation in order to disrupt "the business model of human smuggling and trafficking networks in the South Central Mediterranean". According to the official document, the operation was to be launched after the approval of the Operation Plan and the Rules of Engagement forwarded by the Operation Commander, appointed through the same official document.

A month later, by the Council Decision 2015/972 of 22 June 2015, a new EU operation was indeed launched on the same day, under the official denomination of "European Union military operation in the southern Central Mediterranean (EUNAVFOR MED)".

According to a factsheet updated by the European Union External Action Service on September 2016, the mandate of EUNAVFOR MED is to "undertake systematic efforts to identify, capture and dispose of vessels and enabling assets used or suspected of being used by migrant smugglers or traffickers", thus actively supporting, with military means, the EU's wider ambition to disrupt "the business model" mentioned in Council Decision 2015/778 of 18 May 2015.

Simply put, EUNAVFOR MED is a search and rescue operation meant to baffle the flow of illegal migrants from Libya and neighbouring states to Italy, thus reducing people smuggling and death at sea. It achieves this by patrolling, gathering information, rescuing migrants and neutralizing vessels used by smugglers.

Later in 2015, EUNAVFOR MED was renamed "Sophia", after the name given to a baby born on the ship that rescued her mother - although the "EUNAVFOR MED" denomination still appears in some EU official documents.

According to the factsheet cited above (European Union External Action Service, 2016), although no less than 24 countries are listed as contributing member states to Sophia, only 6 of them have been able to subscribe operating military capabilities (Table no. 1).

Table no. 1.

Military capabilities of Operation Sophia

\begin{tabular}{|c|c|c|c|}
\hline \multirow{2}{*}{ No } & \multirow{2}{*}{ Capabilities } & Type & Contributing Countries \\
\hline \multirow{3}{*}{1} & \multirow{3}{*}{ Ships } & 1 light aircraft carrier & Italy \\
\cline { 3 - 4 } & & 1 destroyer & United Kingdom \\
\cline { 3 - 4 } & & 2 frigates & Spain, France \\
\cline { 3 - 4 } & & 1 mine hunter & Germany \\
\cline { 3 - 4 } & & 1 survey ship & United Kingdom \\
\cline { 3 - 4 } & & 1 auxiliary ship & Germany \\
\hline 2 & Helicopters & 4 organic helicopters & Italy (2), Spain and France \\
\hline 3 & Air assets & 3 of unspecified type & Luxembourg, Spain and France \\
\hline
\end{tabular}


The current mandate of the operation is approved until 27 July 2017, and Sophia's headquarters is located in Rome, in one of the five Europeanised national headquarters from which the EU can conduct an autonomous operation - the other four being established at: Paris (France),
Ulm (Germany), Larissa (Greece) and Northwood (United Kingdom).

And although Operation Sophia has a duration of just over 1 year, it has already scored significant successes, as observable in Figure no. 1 (Operation Sophia, 2016).

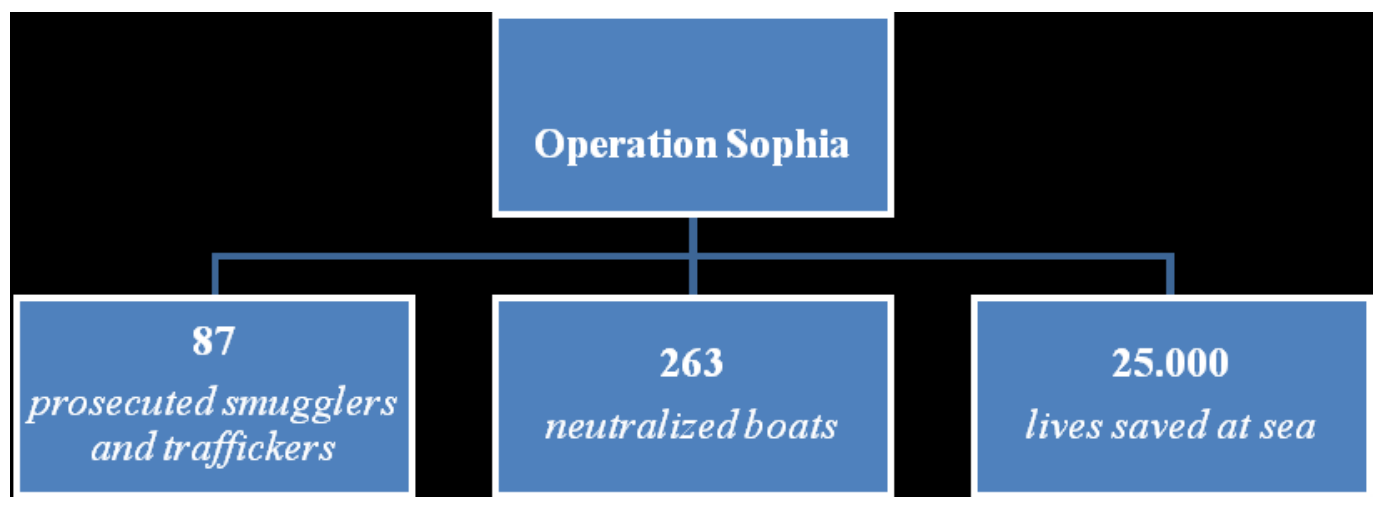

Figure no. 1. Achievements of Operation Sophia in Numbers

On the opportunity and necessity of Operation Sophia, these three numbers speak for themselves.

\section{Discussion on the Shortfalls of Operation Sophia}

One of the first criticisms referred to Operation Sophia concerns the general issue of transparency and in particular the classified Rules of Engagement (ROE).

The ROE - along with the Operation Plan (OPLAN) - have been initially approved by the aforecited Council Decision 2015/972 of 22 June 2015. But, although mentioned in the text of the official document, the ROE are not public.

In a response to a request to declassify these documents, an EU General Secretariat official argued that these are sensitive documents, classified CONFIDENTIAL, and that the release of such information ,could affect the operational effectiveness of this operation and put in danger its personnel" (Thomsen, 2015). Furthermore, a disclosure would "undermine the protection of the public interest as regards the public security and European Union's defence and military matters". And finally, because the "information contained in the documents forms an inseparable whole", the General Secretariat also excludes the possibility of releasing parts of the documents, thus offering at least partial access.

On the one side, we can understand that, due to specific concerns, the content of the OPLAN must not necessarily be disclosed. After all, this is a military document that develops in an extensive manner the Concept of Operations issued by the Operation Commander.

But on the other side, we consider that the ROE ought not to fall under classified information regulations, and ought to be made public and brought to the full attention of all the non-military actors involved in the operation: civilians that may be tempted to migrate, migrants, illegal traffickers, the general population from the Area of Operations (AO). Releasing the ROE would definitely enhance the so necessary transparency of Operation Sophia and would add major points to the overall feeling of trust of the population within the AO towards the intentions of the EU forces.

Operation Sophia also received consistent critiques in an official report 
presented in the Parliament of the United Kingdom. Thus, the $14^{\text {th }}$ Report of Session 2015-2016 was drafted by a special body of the House of Lords, namely the European Union Committee, and was released to the public on 13 May 2016 (prior to the referendum that resulted in the Brexit) under the full name of "Operation Sophia, the EU's naval mission in the Mediterranean: an impossible challenge".

It is true, a part of the British leadership has never been very enthusiastic about the process of European integration or, likewise, about European defence integration, opting instead for a strong commitment within NATO and for their strategic partner, the United States. Yet, we appreciate that the facts and arguments specified in the House of Lords Report are valid and ought not to be neglected, despite the particular view of the British on European affairs and, also, despite the Brexit.

The document first acknowledges the operational progresses achieved and the high number of real human lives saved thanks to Operation Sophia; but it then forwards a set of shortfalls and recommendations that we consider to be both precise and well argued.

On the one hand, the main criticism contained in the report (House of Lords, 2016) refers to the following aspects of Operation Sophia:

a) The search and rescue missions could act as a "magnet to migrants", who would only need to reach the high seas through illegal smuggling, in the hope (or certainty) that from there they will be spotted and brought to safety by the European naval capabilities involved in the operation;

b) The arrests conducted so far have only been low-level targets, making it difficult to obtain major successes in countering the flow of migrants;

c) The destruction of illegal vessels has generated a change in the tactics of the smugglers, who now prefer not to invest in wooden boats, but to mostly acquire the lower-price rubber-dinghies - that are even more dangerous for the safety of the migrants;

d) The mandate and the Conception of Operations for Sophia have been established prior to the intelligence-gathering phase, and this does not necessarily represent a modus operandi in planning military operations;

e) Moreover, as long as intelligence is collected only from the high seas areas, the European political-military deciders will have only a limited understanding of how the illegal traffic networks operate on the mainland of Libya;

f) Finally, Operation Sophia responds to the symptoms, but does not address the causes, because it fails to reach the core of the problem: the weakness of the Libyan state structures and the poor chances for an improvement of the overall security situation in the Middle East and North Africa.

On the other hand, the same report (House of Lords, 2016) contains plausible recommendations, such as:

a) On the short term, focusing efforts on the illegal financial flows generated by the smuggling of migrants;

b) On the medium term, accelerating the implementation of the next phases of Sophia, thus becoming possible for the European military capabilities to operate in Libyan waters and onshore Libya;

c) On the long term, improving the general security climate in the countries of origin for the migrants; although, overall, this is a matter that falls into the responsibility of those countries' governments, the EU could also be of help by providing expert advice and practical assistance.

Deficiencies of Operation Sophia are also ascertained in an analysis published for the Royal United Services Institute by a British author (Roberts, 2016). Roberts considers the plan adopted by the EU to be nothing less than "a failure of EU advisers, ministers and bodies to understand the entirety of the problem to be addressed, to seek relevant lessons on counter-migration policy, or to develop the kind of 
comprehensive approach that could stand a chance of working".

A harsh critique indeed, based on the following drawbacks of Operation Sophia:

a) A full inspection of the illegal vessels, prior to destruction, to ensure that they do not conceal civilians (migrants) in less accessible areas (below the deck) is very difficult to undertake, as it requires considerable human and time resources;

b) It is unclear how the disruption of the business model of illegal migration can be accomplished from hundreds of miles away from the Libyan territory;

c) Even more, this disruption requires investigation and prosecution - skills and authorities that are rather specific to police forces, and not to the typical military personnel;

d) The operation could divert naval military capabilities from other priorities. As the assumed search and rescue area is rather large, supporting Sophia in an effective manner would require redirecting already scarce military capabilities from other national and regional security concerns (such as countering Russian influence in the Baltic Sea or combating pirates in the Gulf of Aden);

e) The plan does not consider successful lessons learned from similar operations conducted by other naval powers (the United States, Australia), especially the need to repatriate the migrants;

f) The operation fails to address the root causes. As the author figuratively argues, "migrants in boats are symptoms, not causes of the problem". Even if the Libya - Italy route for migrants will be cleared, illegal smugglers will surely find other ports, coasts and boats to get asylum seeking migrants straight to Europe (Spain is, in this regard, mentioned as an example for an alternative to Italy).

The long term solution consists (as also noticed in the 2016 House of Lords Report) in enhancing the overall state of human security in the migrants' countries of origin, by tackling the conventional threats, but also the vast array of everevolving hybrid threats (Cîrdei, 2016).

Finally, one last criticism on Operation Sophia has been overtly forwarded by Libyan authorities. In a June 2016 interview, the Head of the coastguard operations argued that, since the existence of Sophia, migrants fell even more prone to risking their safety for the promise of a more decent life on the European continent. The official even described, in a very accurate and prosaic manner, a new tactic employed by migrants with the launch of Operation Sophia: „People, when they get rescued, call their friends to tell them that there are EU vessels only 20 miles away from Libyan waters to save them" (EUobserver, 2016).

\section{Conclusions}

The EU military Operation Sophia is currently short on popularity, although its' achievements suggest otherwise; in just over one year, conducting this operation resulted in 87 prosecuted smugglers and traffickers, 263 neutralized boats and 25.00 lives saved at sea.

But, even having scored important successes, like as any other endeavour of its kind, Operation Sophia is far from being perfect. Revisiting its main shortfalls, we can assert that: it lacks a certain degree of transparency, as the Rules of Engagement have not yet been made public; it tends to impel illegal immigration, as migrants now feel that they have a better chance of reaching Europe; it addresses the symptoms, and not the root causes of the existing migration phenomenon.

In our opinion, all these analysed deficiencies ought to constitute new occasions for reflection that should generate, in return, concrete, workable solutions for enhancing the so opportune EU military Operation Sophia. 


\section{Acknowledgement}

This paper has been elaborated during the sustainability period of the project entitled „Horizon 2020 - Doctoral and Postdoctoral Studies: Promoting the National Interest through Excellence, Competitiveness and Responsibility in the Field of Romanian Fundamental and Applied Scientific Research", contract number POSDRU/159/1.5/S/140106. This project was cofinanced by European Social Fund through Sectoral Operational Programme for Human Resources Development 2007-2013. Investing in people!

\section{REFERENCES}

Chelcea, S. (2004). Iniţiere în cercetarea sociologică. Bucureşti: Comunicare.ro, 235-262.

Cîrdei, I.A. (2016). Countering the Hybrid Threats. Revista Academiei Forţelor Terestre, vol. XXI, 115-116.

Council Decision. (2015). Council Decision (CFSP) 2015/778 of 18 May 2015 on a European Union military operation in the Southern Central Mediterranean (EUNAVFOR MED). Official Journal of the European Union, L122/31, 19 May 2015.

Council Decision. (2015). Council Decision 2015/972 of 22 June 2015 launching the European Union military operation in the southern Central Mediterranean (EUNAVFOR MED). Official Journal of the European Union, L157/51, 23 June 2015.

Euobserver. (2014). EU boosts migrant smuggling, says Libyan coastguard, available at: https://euobserver.com/tickers/133849, accessed at: 17 September 2016.

European Union External Action Service. (2016). European Union Naval Force Mediterranean Operation Sophia, available at: https://eeas.europa.eu/csdp/missions-andoperations/eunavfor-med/pdf/factsheet_eunavfor_med_en.pdf, accessed at: 14 September 2016.

House of Lords. (2016). Operation Sophia, the EU's naval mission in the Mediterranean: an impossible challenge, London: Authors.

Operation Sophia. (2016). Press release 001/2016, Rome, 30 August 2016.

Roberts, P. (2015). Militarising the EU Migration Plan: A Flawed Approach. The Royal United Services Institute, Newsbrief, vol. 35, no. 4.

Thomsen, J. (2015). Head of Unit, General Secretariat of the Council of the European Union. Response to Request of Ms Ilaria Tani, Ref. 15/2422-nh/jj, available at: https://www.asktheeu.org/en/request/eunavfor med operation sophia op\#incoming-8234, accessed at: 13 September 2016. 